IRA-International Journal of Education \&

Multidisciplinary Studies

ISSN 2455-2526; Vol.17, Issue o3 (Q3, 2021)

Pg. no. 150-156.

IRA Academico Research

\title{
Frameworks of Intercultural Language Teaching: A Review
}

\author{
Long Chen ${ }^{1}(i)$ \& Peng Yi ${ }^{2 \# ~(i) ~}$ \\ ${ }^{1,2}$ School of Foreign Studies, Yangtze University. Hubei, 434023 P.R. China.
}

\#corresponding author

Type of Work: Peer Reviewed.

DOI: 10.21013/jems.v17.n3.p5

DOI URL: https://dx.doi.org/10.21013/jems.v17.n3.p5

\begin{abstract}
Chen, L., Yi, P. (2021). Frameworks of Intercultural Language Teaching: A Review. IRA-International Journal of Education \& Multidisciplinary Studies (ISSN 2455-2526), 17(3), 150-156.
\end{abstract}

DOI: https://dx.doi.org/10.21013/jems.v17.n3.p5

(C) IRA Academico Research.

(c) EY-No This work is licensed under a Creative Commons Attribution-NonCommercial 4.0 International License subject to a proper citation to the publication source of the work.

Disclaimer: The scholarly papers as reviewed and published by IRA Academico Research are the views and opinions of their respective authors and are not the views or opinions of IRA Academico Research. IRA Academico Research disclaims any harm or loss caused due to the published content to any party.

IRA Academico Research is an institutional publisher member of Publishers International Linking Association Inc. (PILA-CrossRef), USA. IRA Academico Research is an institutional signatory to the Budapest Open Access Initiative. Hungary advocating the open access of scientific and scholarly knowledge. IRA Academico Research is a registered content provider under Open Access Initiative Protocol for Metadata Harvesting (OAl-PMH).

The journal is indexed \& included in WorldCat Discovery Service (USA), CrossRef Metadata Search (USA), WorldCat (USA), OCLC (USA), Open J-Gate (India), EZB (Germany) Scilit (Switzerland), Airiti (China), Bielefeld Academic Search Engine (BASE) of Bielefeld University, Germany, PKP Index of Simon Fraser University, Canada.

${ }^{1}$ Long Chen is a postgraduate of QZ206 in the School of Foreign Studies. Yangtze University. ${ }^{2}$ Peng Yi (corresponding author) is an Associate Professor in the School of Foreign Studies, Yangtze University. He is interested in language education. 


\begin{abstract}
This article mainly summarizes the important achievements of domestic intercultural teaching research from the perspective of intercultural competence and teaching and finds that the research of intercultural teaching has gradually shifted from being teacher-centred to learner-centred, focusing on the influence factors of intercultural teaching intervention by different methods and students' intercultural and the improvement of communicative competence, and the teaching paradigm. However, the application background of existing research has certain limitations, and insufficient attention has been paid to learners' own differences. Future research can further research on specific level one or all level students explore ways and methods to effectively improve the intercultural knowledge and abilities of second language learners, and further, promote the optimization of intercultural knowledge acquisition and implement and teaching theories.
\end{abstract}

Keywords: intercultural communication, intercultural communication teaching, ICC

\title{
Introduction
}

With the development of globalization, more and more international communication and cooperation will follow, which will inevitably lead to an urgent need for comprehensive diplomatic talents with intercultural communication skills. How to make English teaching meet the needs of social and economic development and how to improve students' intercultural communication skills are new requirements for English teachers and current English teaching. This also means that we must permeate intercultural teaching in English teaching to improve students' intercultural awareness. This article aims to sort out and review the important research results of intercultural language teaching and provide a reference for follow-up research, from three dimensions: the definition of cultural and intercultural communicative competence under the framework of intercultural communication, the ways to cultivate students' intercultural communicative competence, and how to improve Students' intercultural communicative competence in teaching.

\section{The Definition of Culture}

Since the 18th century, scholars have tried to define culture, but they all failed. As Dingfang, S. (1996) pointed out; all aspects of human life are permeated and influenced by culture. So, it becomes more difficult to make an accurate description of culture. Taylor (1871) proposed that culture is a hybrid, which not only includes knowledge, customs, morals, beliefs, art, and law but also includes other abilities and habits acquired by individual members of society. This is the first academic definition of the concept of culture. Although he did not explain and classify specific content of culture, he provided the foundation and pavement for future generations to expand and derive the definition of culture. According to E. Sapir (1921), "Culture may be defined as what a society does and thinks." After Taylor, many scholars have put forward their ideas in favour or against, and the debate on the definition of culture has never stopped. However, Jinzhou, Z. (2000) defines culture as "all concepts and behaviours acquired and shared by a certain social group". The well-known Chinese scholar Wenzhong, H. (2012) also proposed that culture is the whole life of humans and civilization, which includes all explicit and non-obvious, appropriate, and inappropriate, and they have potential influences on people's behaviour under a specific era. From my perspective, I prefer the definition from New English Curriculum Standard (2017), "culture involved in foreign language teaching mainly refers to Chinese and foreign cultural knowledge and the appropriate usage, which includes both material and spiritual aspects." It implied that when we are teaching a foreign language, understanding the domestic culture is as important as foreign culture. What's more, cultivating the ability to compare different characteristics between two languages and cultural backgrounds by students themselves also should be paid enough attention. 


\section{The Definition of Intercultural Communicative Competence}

It is widely accepted that intercultural communication competence refers to the ability that one can use the target language correctly, effectively, and appropriately when communicating with people from different cultures in different intercultural contexts.

Bennett (2001) defines "intercultural competence" as, "the general ability to transcend ethnocentrism, appreciate other cultures and generate appropriate behaviour in one or more different cultures". Byram (1997) defined intercultural communicative competence as the knowledge, skills, and ability to participate in an activity coded in the target language, and the ability to participate in activities organized by individuals with different language backgrounds. So Byram (2002) believe that intercultural competence is the ability to change one's knowledge, attitude and behaviour in order to adapt to other cultures openly and flexibly. Deardorff (2006) believes that intercultural communicative competence is manifested as a collection of attitudes, methods, special behaviours, and reflective abilities that promote integration in an intercultural context. Wen (1999) believes that "intercultural communicative competence includes communicative competence and intercultural competence. Communicative competence includes language competence, pragmatic competence, and strategic competence. Intercultural competence includes sensitivity, tolerance, and flexibility."

Hongling, Z., \& Chunyu, Y. (2020) pointed out that "the ultimate goal of cultural learning and language learning is to understand more cultural groups, master the common rules of cultural communication, improve intercultural awareness, and improve intercultural communication skills." Be able to carry out intercultural communication, and ultimately strive to become a successful intercultural communicator. Among them, Byram's intercultural communication competence model (Byram 1997, 2008) including five dimensions of knowledge, connection skills, discovery skills, attitude, and awareness is one of the most influential theoretical models. When scholars try defining it, they also tend to define it in terms of attitude, consciousness, and skills.

\section{The Frameworks for Cultivating ICC}

Byram proposed five objectives for teaching, learning, and assessing that intercultural communicative competence is attitude, knowledge, skills of discovery, skills of relating and critical cultural awareness. The way to become such kind of intercultural citizen could be that learning, by comparison, learning in one's own country (especially linguistic/ethnic minorities), learning in activities outside school and try to make class-to-class links to compare and act on a topic in two or more countries.

More specifically, the 4Cs framework of CLIL focuses on the interrelationship between content (subject matter), communication (language), cognition (learning and thinking) and culture (social awareness of self and "otherness"). It takes account of "integration" on different levels: learning (content and cognition), language learning (communication and cultures) and intercultural experiences. (Do Coyle, 2007)

According to Liddicoat (2001), intercultural language learning is captured in five principles that guide curriculum design and classroom interaction. They are active construction, making connections, social interaction, reflection, and responsibility. These five principles provide a basis for teachers of language to use in making choices and decisions in planning programs for student learning, teaching, resourcing, assessing to monitor and describe progress in learning over time and in evaluating and renewing the curriculum. The processes are not linear in a relationship but rather all processes may be co-present in any instance of teaching and learning. Interacting processes of intercultural pedagogy is trying to involve students in a process of noticing, comparing, reflecting, and interacting. Thus, constructing the background culture of the learner and the target culture as equally valid representations of human life and encourage students' knowledge assimilation. Real situations always help a lot, so viewing instances of language use as experiences of culture and opportunities for culture learning may exert great influences. 
And learning through communication which is focusing on the capabilities required for ongoing learning about cultures through experiences of language. Cultural diversity encourages the inclusion of multiple perspectives. As Hongling, Z. (2012) said, we could do a lot to enhance intercultural teaching, no matter on a macro-level or micro level. On the macro level, the theoretical and practical problems should have more discussion and try to keep the consistency between them. The related syllabus should be made and the adjust curriculum systems, renew the teaching methods and activities, compile the textbooks with great care. On the micro-level, experimental research on intercultural foreign language teaching needs to be conducted and try to apply ideas in classroom or teacher training.

Intercultural sensitivity is an important part of ICC, so Bennett (1999) have established a culture-general model for the acquisition of intercultural sensitivity, the Developmental Model of Intercultural Sensitivity (DMIS), which seeks to explain how learners' abilities to operate in an intercultural context, to identify and appreciate cultural differences, and to develop strategies for dealing with cultural differences in communication, evolve over time. The model is made up of two broad stages: ethnocentrism and ethno-relativism. Ethnocentrism is defined by Bennett et al. as a disposition to view one's own cultural point of view as central to reality, while ethno-relativism is the conscious recognition that all behaviour exists within a cultural framework, including one's own. Bennett et al. argue that the starting point for all intercultural competence lies in ethnocentrism and that learners move towards progressively greater levels of ethno-relativism as the result of exposure to and reflection on cultural differences. Both ethnocentrism and ethno-relativism are further divided into three stages which are developmentally ordered. The stages of ethnocentrism are denial, defence, and minimization. The stages of ethno-relativism are acceptance, adaptation, and integration. This process not only focuses on the discrete learning facts but also the development of an intercultural mindset. Because it highlights generalizable intercultural skills and awareness that learners acquire from learning culture in relation to a particular language. For teachers, the model emphasizes the need for a sensitive approach to issues of cultural similarity and difference, which parallels decisions that languages teachers already make with respect to how they deal with linguistic similarities and differences. At the same time, he put forward many ways to improve students' DMIS, such as The Assimilationist approach, the "Capital C" Culture approach, the Assimilationist approach, the diversity Lite approach, "Isms" approach, Legal approach, Intercultural Developmental approach.

\section{The Ways of Cultural Knowledge Learning}

Paige et al. (1999) provide a useful working definition of culture learning, which can form a starting point for a consideration of ways of developing more effective language education: Culture learning is the process of acquiring the culture-specific and culture-general knowledge, skills, and attitudes required for effective communication and interaction with individuals from other cultures. It is a dynamic, developmental, and ongoing process which engages the learner cognitively, behaviorally, and affectively (Paige et al., 1999: 50).

In general, the way of culture learning should be learner-centred. The learners need to explore the target language and culture and their own language and culture, and then try to discover the relationship between language and culture. In this process, conceptual and analytic tools will be developed for comparing and understanding cultures with a reflective capacity to deal with cultural differences and to modify behaviour where needed.

For teachers, Liddicoat believes that culture is integrated into language macro skills, not a separate macro skill, so the culture needs to be taught simultaneously with and integrated into language teaching. At the same time, it will be better when culture is taught from the beginning of language learning and is not delayed until learners have acquired some of the languages. The key concern here is that delaying input about culture does not delay culture learning, but rather leads to false culture learning as a result of a lack of awareness of difference and does 
not begin the process of thinking about one's own culture. Culture learning primarily involves learning how to discover new information about the culture while engaging with the culture. No program of teaching culture can ever cover a whole culture and, as a result, factual approaches to culture teaching are of limited future benefit for the learner. Based on these principles, Liddicoat and Crozet (2001) have proposed a model for intercultural language teaching which consists of a four-step process of awareness-raising, experimentation, production, and feedback.

Essentially, raise the intercultural awareness of students will be the most effective way. For example:

一位在美的留学生, 想要考驾照。在考试时因为过于紧张, 看到地上标线是向左转。

他不放心的问道: turn left?

监考官回答: right。于是他立刻向右转……

In that case, the students did not understand the examiner and made a funny mistake. After the joke, students will understand the word from another angle and realize the importance of word usage in a real situation, then raising cultural awareness.

And for teachers who really conduct the classes, more attention may be given to the way of introducing knowledge appropriately. The culture knowledge could be implanted without awareness.

For example green sometimes represents jealous, so '眼红' should be translated as green-eyed rather than red-eyed.

In daily conversations, students are most likely to make pragmatic errors. This is not only because dialogue involves the standardized use of communicative language and etiquette customs, but also because in specific verbal communication, the choice of language forms is always affected by the time, place, topic, emotions, personalities, social roles, and cultural backgrounds of both parties. And other contextual factors, therefore, in addition to letting students remember relevant communicative language and impart necessary cultural background knowledge, specific communicative contexts should also be set up. In these processes, students could flexibly choose appropriate training methods, and be encouraged to engage in oral or written, bilateral or multilateral language practice activities; Role-play or extracurricular activities, such as English Corner and English Festival.

In the context of Chinese education, it may be workable for teachers to dig out cultural information in the textbooks. The current English textbooks have a wide selection of materials, and most of the texts involve the typical cultural background knowledge of English-speaking countries, especially the literary works in them, which provide vivid materials for students to understand the country. In discourse teaching, teachers should not only encourage students to grasp the content of the article, learn language knowledge and improve language skills but also guide them to dig out cultural information anytime and anywhere. For example, when we meet Mr Smith, Mrs Smith, Miss Marie in textbooks, teachers could try to guide students to summarize the usage of the appellation.

More effectively, systematize and simplify intercultural knowledge in the process of summarizing. For example, the taboos in the conversation between Chinese and English-speaking people can be summarized into some formulas, which is convenient for memory.

\section{The Application of Domestic Intercultural Studies in Foreign Language Teaching}

\section{Teachers' understanding of Chinese culture teaching in English class}

According to Zhen Zhen (2020), she found that English teachers in a certain city mostly understand the necessity of intercultural communication teaching and the reasons have been concluded. Firstly, comprehensive language ability means not only mastering vocabulary or grammar but traditions, habits, geography and so on. Enough knowledge input will contribute to students' output, which means communications between foreigners and them will be smoother. Also, students will deepen their understanding of the significance of culture in the 
process of comparison of cultural differences. More importantly, ICC will be developed gradually.

\section{Provision and implementation of the New Curriculum}

The requirements of English Curriculum Standards of Senior High School (2003) and core competencies in English courses about cultural awareness and ICC are not implemented well in senior high school English classes. Based on the research conducted by Mudan, X. (2020), teachers' teaching behaviours and teachers' emotional attitudes reflected the inconsistency of theory and practice. The reasons behind the phenomenon are varied (Yixuan, S. 2020). In the perspective of teachers, some teachers have been affecting by prior and traditional teaching methods in their teaching behaviours and methods. Thus, focusing more on knowledge and skills and ignoring the culture and did not dig deep into the concepts and contents in the teaching materials. Even if the textbook content involves foreign culture, teachers still concentrate on the interpretation of basic knowledge and skills of language, thus ignoring the explanation of cultural knowledge. Meanwhile, examination-oriented education places great importance on test scores, so it will undoubtedly have a direct impact on English teaching. So, there may be some teaching resources, like textbooks, but the teaching methods and resources are relatively single in cultural knowledge teaching. Hence, students sometimes misunderstand foreign cultural phenomenon that causes the failure in intercultural communication and the low level of students' ICC.

As we all know, teachers act as leaders in most classes, especially in the lower grades. Thus, the content output by teachers has become the main source of input by students. Whether teachers will pay attention to the cultivation of ICC influences a lot. Siyuan, S. \& Jialin, C. (2011) have conducted research, which attempts to explore the present state of the intercultural sensitivity of English teachers in senior high schools. The results show that the overall intercultural sensitivity of English teachers in these four high schools is in a good state. In the specific five levels, the sense of different identity is the strongest, followed by the degree of communication participation, communication pleasure, communication focus, and communication confidence. This is closely related to teachers' lack of intercultural training and practical communication. However, in the actual teaching process, cultural teaching has not received due attention, and the traditional teacher-centred teaching method is still the mainstream in middle school. The complexity of cultural content, the pressure of college entrance examinations, and the arduous teaching task are all potential causes of this phenomenon.

\section{Conclusion}

This research analyzes and summarizes the training and teaching models of intercultural competence at home and abroad, the definition of intercultural communicative competence from different perspectives and the specific application in China. In the future, we need to combine the characteristics of foreign language teaching in different stages and strive to develop a universal frame covering intercultural teaching in every stage. At present, there are many intercultural competence training models, but the domestic background should still be considered when in a real class. The research on intercultural competence in China should be based on the Chinese context, serving for the cultivation of talents. As the ultimate goal of foreign language teaching, the cultivation of intercultural competence should infiltrate every link in the cultivation of foreign language skills (listening, speaking, reading, writing, and translation).

\section{References}

[1]. Bennett, J., \& Bennett, M. (2004). Developing intercultural sensitivity: an integrative approach to global and domestic diversity. In D. Landis J. M. Bennett, \& M. J. Bennett Handbook of intercultural training (pp. 147-165). SAGE Publications, Inc., https://www.doi.org/10.4135/9781452231129.n6

[2]. Bennett, M.J. (1979) Overcoming the Golden Rule: Sympathy and Empathy, Annals of the International Communication Association, 3:1, 407-422, DOI: 10.1080/23808985.1979.11923774

[3]. Byram, M. (2008). From Foreign Language Education to Education for Intercultural Citizenship: 
Essays and Reflections. Bristol, Blue Ridge Summit: Multilingual Matters. https://doi.org/10.21832/9781847690807

[4]. Byram, M. (1997). Teaching and assessing intercultural communicative competence. Bristol, UK: Multilingual Matters.

[5]. Liddicoat, Anthony. \& Lo Bianco, Joseph. \& Crozet, Chantal. (1999). Striving for the third place: intercultural competence through language education. Melbourne: Language Australia.

[6]. Coyle, D. (2007) Content and Language Integrated Learning: Towards a Connected Research Agenda for CLIL Pedagogies, International Journal of Bilingual Education and Bilingualism, 10:5, 543-562, DOI:https://doi.org/10.2167/beb459.0

[7]. Sapir, E. (1921). The Sounds of Language. Language. New York: Harcourt Brace.

[8]. Wenzhong, H. (2012). An Introduction to Cross-cultural Communication [M] Foreign Language Teaching and Research Press.

[9]. Hao Lu. (2013). Research on the weakness of cultural awareness in senior high school English teaching. English Square. (02),161. DOI: 10.16723/j.cnki.yygc.2013.02.099.

[10]. Ministry of Education of the People's Republic of China. (2017). National English curriculum standards for general high school. People's Education Press.

[11]. Siyuan, S. \& Jialin, C. (2011). An investigation into senior high school English teachers 'intercultural sensitivity. Foreign Language Research (03),144-147. doi:10.16263/j.cnki.23-1071/h.2011.03.001.

[12]. Dingfang, S. (1996). The relationship between language and culture and the introduction of culture in basic foreign language teaching Foreign Language World (01), DOI:CNKI:SUN:WYJY.0.1996-01-002.

[13]. Yixuan, S. (2018).A study on the cultivation of intercultural communicative awareness in senior high school English teaching (Master Thesis, Ludong University).

[14]. Tylor, E. B. (1924). Primitive culture, Vol 2 (7th ed.). New York NY: US Brentanos: Primitive Culture.

[15]. Mudan, X. (2020). Cultivating middle school students' cultural awareness: from the perspective of English teachers' perceptions (Master Thesis, Qingdao University).

[16]. Jinzhou, Z. (2000). Educational culture. People's Education Press.

[17]. Hongling, Z. (2012). Intercultural education-oriented foreign language teaching: History, status and future. Foreign Language World (02), 2-7.

[18]. Hongling, Z., \& Chunyu, Y. (2020). Constructing an integrated model for Chinese students 'intercultural competence development. Foreign Language World (4), 35-44.

[19]. Zhen Zhen. (2020). A survey of Chinese culture teaching English Class of senior high school—based on M City No.1 Senior High School (Master Thesis, Mudanjiang Normal University). 